\title{
ANTIPROLIFERATIVE AND ANTIOXIDANT ACTIVITY OF LEAVES EXTRACTS OF MORINGA OLEIFERA
}

\author{
BURLI SANGANNA1, HAVAGIRAY R. CHITME², KHANVILKAR VRUNDA¹, MOHSIN J. JAMADAR³
}

1Department of Pharmacology, Tatyasaheb Kore College of Pharmacy, Warananagar 416113, ${ }^{2}$ Departments of Pharmacy, Oman Medical College Oman Medical College, Bausher Campus, Muscat-Oman, ${ }^{3}$ Appasaheb Birnale College of Pharmacy, Sangli Depatment of Quality Assurance

Email: scburli@gmail.com

Received: 28 Jul 2016, Revised and Accepted: 06 Sep 2016

ABSTRACT

Objective: The aim of the study was to investigate the ethanolic and aqueous extract of leaves of Moringa oleifera for phytochemical constituents, antiproliferative and antioxidant activity.

Methods: The ethanolic extract of leaves of Moringa oleifera, belonging to the family Moringaceae was prepared by using soxhlet apparatus and aqueous extract was prepared by using maceration process. The extract was evaluated for its phytochemical constituents. The antiproliferative effects of both extracts were checked by using MTT ([3-(4,5-Dimethylthiazol-2-yl)-2,5-Diphenyltetrazolium Bromide]) assay on HT-29 colon cell line and the antioxidant activity were checked by using DPPH (2,2-diphenyl-1-picrylhydrazyl) assay. In antiproliferative and antioxidant activity the 5-FU (5-fluro uracil) and Ascorbic acid used as a standard drug for present results conclusion respectively.

Results: The results obtained in MTT assay shown that ethanolic extract of Moringa oleifera had a more potent antiproliferative effect (growth inhibition of $62.25 \%$ at $100 \mu \mathrm{g} / \mathrm{ml}$ ) on HT-29 colon cell line as compared to aqueous extract (\% growth inhibition of 27.86 at $100 \mu \mathrm{g} / \mathrm{ml}$ ) of Moringa oleifera. The ethanolic extract of Moringa oleifera shown more potent antioxidant activity (\% inhibition of ethanolic 75.57 at $100 \mu \mathrm{g} / \mathrm{ml}$ ) than aqueous extract (38.16 at $100 \mu \mathrm{g} / \mathrm{ml}$ ) of Moringa oleifera. The activity shown by the extract is concentration dependent.

Conclusion: In the present study we have investigated that the effect of ethanolic and aqueous leaves extracts of Moringa oleifera possess antiproliferative and antioxidant properties.

Keywords: Antiproliferative, Antioxidant, MTT assay, DPPH assay, HT-29 colon cell line

(C) 2016 The Authors. Published by Innovare Academic Sciences Pvt Ltd. This is an open access article under the CC BY license (http://creativecommons.org/licenses/by/4.0/) DOI: http://dx.doi.org/10.22159/ijcpr.2016v8i4.15278

\section{INTRODUCTION}

Cancer is the largest single cause of death in both men and women. The Cancer cells typically invade and destroy normal cells. The major causes of cancer are dietary imbalances, smoking, hormones imbalances and chronic infections leading to chronic inflammation [1]. In India, colorectal cancer frequency has been increasing in recent years because of change in lifestyle of diet and environment factors. The dietary is the one of the prevalence factors for colon carcinogenesis due to having high fat, high protein and low carbohydrate; low fibers are implicated as stir up agent in epidemiological and animal studies [2]. Colorectal cancer (CRC) is the third most common cancer in the world and the third leading cause of cancer-related mortality in the United States [1].

Mutation is to account for most cancer, including colorectal. The cascade of events proposed to account for the development of a neoplasm in normal colonic epithelial tissue and leads to multiple polyps [3]. Some evidence suggests that the diet is an important environmental factor in the development of colon cancer and high consumption of red meats, animal fats, chocolate, alcohol and refined cereals are linked to higher incidence of cancer [4]. Natural dietary antioxidants compounds such as fruits and vegetables protect against damages caused by reactive oxidants [5]. Hence in the present study, we selected vegetables as one of the anticancer agents on HT-29 cell line

Moringa oleifera known as Moringa is native to north India having the bioactive potency for antibacterial, antifungal and secondary metabolites which are frequently used in traditional medicine as a reference to its curative power in colon cancer [6] and some other diseases [7]. Leaves of Moringa oleifera serve as a valuable source of nutrient for all age groups and play a role in fighting malnutrition [8]. India has the prime position in the cultivation and production of Moringa oleifera. So researchers have become influenced that nutrients found in fruits and vegetables do more than just prevent deficiency diseases [8] and a high consumption of fruits and vegetables reduced the risk of cancer [9].

The leaves are highly nutritious, which contain more vitamin A, calcium, iron, vitamin $\mathrm{C}$ and potassium. Moringa oleifera is rich in various phytochemicals like carotenoids, vitamins, minerals, amino acids, sterols, glycosides, alkaloids, flavonoids, moringine, moringinine, phytoestrogens and phenolics in flowers, leaves, roots, fruits and seeds, etc [9]. Consideration into above data, in account of use as a folk medicine of Moringa oleifera and its prevalent claims of the medical effectiveness and the lack of experimental studies on its in vitro HT-29 cell line activity, hence the present investigation was undertaken to evaluate the antiproliferation and antioxidant activity of the aqueous and ethanolic extract of Moringa oleifera on HT-29 human colon cell lines.

\section{MATERIALS AND METHODS}

\section{Plants}

In the present study, the Moringa oleifera leaves were collected from the local area. The leaves were authenticated by Dr. S. Y. Jadhav, H. O. D of Botany. Yashwantrao Chavan Science College, Warananagar, Kolhapur, Maharashtra India, studies include organoleptic tests, and macroscopic and microscopic observations were done. Then voucher specimen is deposited at Science College and the number is YCS/BOT/29. Soon after authentication, the leaves were used for polar and nonpolar solvent extraction by using a soxhlet apparatus then extract was subjected for phytochemical investigation.

\section{Cell culture}

HT-29 human colon cancer cells were obtained from NCL, Pune, India The cells were maintained in the laboratory. 2, 2 diphenyl picrylhydrazyl (DPPH), as a reagent was purchased from Sigma, dissolved to $5 \mathrm{mmol} / \mathrm{l}$ in DMSO as a stock solution. MTT reagent was purchased from Sigma. The two solutions were preserved at $4{ }^{\circ} \mathrm{C}$ 


\section{Cell lines culture}

In in vitro antiproliferative activity, the human colon cell lines (HT29 colon) were tested. The cell lines were obtained from NCL, Pune, India. The cell lines were cultured in RPMI 1640 medium supplemented with $5 \%$ of fetal bovine serum, $100 \mathrm{U} / \mathrm{ml}$ penicillin and $0.1 \mathrm{mg} / \mathrm{ml}$ streptomycin at $37{ }^{\circ} \mathrm{C}$ in a humid atmosphere containing $5 \% \mathrm{CO}_{2}$.

\section{Antiproliferative assay}

The cells $(100 \mu \mathrm{l} /$ well, at a density of 3-6 $\times 104 \mathrm{cell} / \mathrm{ml})$ were plated in 96-well plates and incubated with sample at various concentrations ( 0.25 to $250 \mu \mathrm{g} / \mathrm{ml}, 100 \mu \mathrm{l} /$ well) in DMSO/RPMI $1640 /$ FBS $5 \%$ at $37^{\circ} \mathrm{C}$ and $5 \%$ of CO2 in air for 48 h. Final DMSO concentration did not affect cell viability.

Cells were then fixed with $50 \%$ trichloroacetic acid, and cell proliferation was determined by spectrophotometric quantification of cellular protein content at $540 \mathrm{~nm}$, using the MTT assay [10].5flurouracil $(3.125-100 \mu \mathrm{g} / \mathrm{ml})$ used as the positive control in this assay. Three measurements were obtained at the beginning of incubation (time zero, $\mathrm{T} 0$ ) and $48 \mathrm{~h}$ post incubation for compoundfree $(\mathrm{C})$ and tested (T) cells.

$$
\begin{gathered}
\text { Surviving cells }(\%)=\frac{\text { Mean OD of Control }- \text { Mean OD of test }}{\text { Mean OD of control }} \times 100 \\
\% \text { cell inhibition }=100-\% \text { cell survival }
\end{gathered}
$$

The effects of extracts were expressed by IC50 values calculated from dose response curves.

\section{Antioxidant activity}

For assessment of DPPH radical scavenging activity, DPPH solution was prepared by dissolving $4 \mathrm{mg}$ DPPH in $100 \mathrm{ml}$ methanol. A dilution series were prepared for ascorbic acid and extract. After that $5 \mathrm{ml}$ of sample solution was mixed with $0.5 \mathrm{ml}$ DPPH solution and incubated for $30 \mathrm{~min}$ at room temperature in dark condition and absorbance was taken at $517 \mathrm{~nm}$ and calculated the \% inhibition of DPPH radical [11]. $\%$ inhibition of DPPH radicals $=\frac{\text { Absorbance of control }- \text { Absorbance of Sample }}{\text { Absorbance of control }} \times 100$



Fig. 1: It shows that the percentage inhibition or cytotoxicity in HT-29 human colon cancer cell lines of Moringa oliefera ethanolic and aqueous extracts (3.125 to $100 \mu \mathrm{g} / \mathrm{ml})$ compared to 5-Fluro uracil as a standard drug. Values are expressed as inhibition Vs Concentration

\section{RESULTS}

\begin{tabular}{|c|c|c|c|c|c|c|c|c|}
\hline \multirow[t]{2}{*}{ S. No. } & \multirow[t]{2}{*}{ Concentration $(\mu \mathrm{g} / \mathrm{ml})$} & \multicolumn{2}{|c|}{$\begin{array}{l}\text { Moringa Oliefera } \\
\text { (\%) Cytotoxic activity }\end{array}$} & \multicolumn{2}{|c|}{$\begin{array}{l}\text { Moringa Oliefera } \\
\text { IC }_{50}(\mu \mathrm{g} / \mathrm{ml})\end{array}$} & \multicolumn{3}{|c|}{$\begin{array}{l}\text { Moringa Oliefera } \\
\mathbf{R}^{2}\end{array}$} \\
\hline & & Aqueous & Ethanolic & 5-FU & Aqueous & Ethanolic & Aqueous & Ethanolic \\
\hline 1 & 100 & 27.86 & 62.25 & 81.81 & Very wide & 59.63 & 0.982 & 0.870 \\
\hline 2 & 50 & 17.59 & 54.31 & 73.63 & & & & \\
\hline 3 & 25 & 12.77 & 41.77 & 66.00 & & & & \\
\hline 4 & 12.5 & 9.5 & 29.18 & 59.00 & & & & \\
\hline 5 & 6.25 & 8.1 & 22.59 & 51.00 & & & & \\
\hline 6 & 3.125 & 4.9 & 18.81 & 43.69 & & & & \\
\hline
\end{tabular}

Table 1: Antiproliferation activity of aqueous and ethanolic extract of Moringa oliefera

Table 2: Antioxidant activity of aqueous and ethanolic extract of Moringa Oliefera

\begin{tabular}{lllll}
\hline S. No. & $\begin{array}{l}\text { Concentration } \\
(\boldsymbol{\mu g} / \mathbf{m l})\end{array}$ & $\begin{array}{l}\text { \% inhibition of Standard } \\
\text { ascorbic acid }\end{array}$ & $\begin{array}{l}\text { \% inhibition of } \\
\text { aqueous extract of } \text { Moringa } \text { Oliefera }\end{array}$ & $\begin{array}{l}\text { \% inhibition of } \\
\text { Ethanolic extract of } \text { Moringa } \text { Oliefera }\end{array}$ \\
\hline 1 & 20 & 64.17 & 22.90 & 44.27 \\
2 & 40 & 68.65 & 27.48 & 50.38 \\
3 & 60 & 71.14 & 29.00 & 54.96 \\
4 & 80 & 78.60 & 33.58 & 68.70 \\
5 & 100 & 87.56 & 38.16 & 75.57 \\
\hline
\end{tabular}

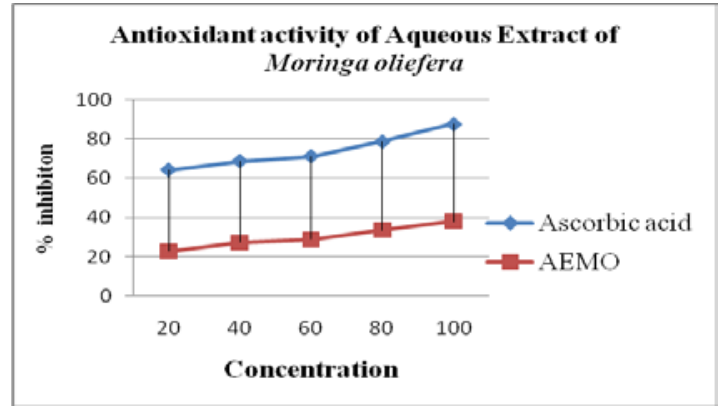

Fig. 2: It shows that the percentage inhibition in DPPH radical scavenging activity of Moringa oliefera aqueous extracts (20 to $100 \mu \mathrm{g} / \mathrm{ml}$ ) compared to standard drug ascorbic acid. Values are expressed as inhibition Vs concentration

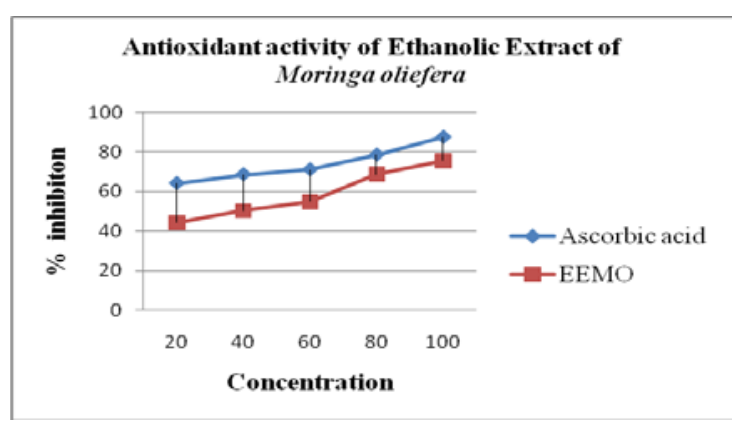

Fig. 3: It shows that the percentage in DPPH radical scavenging activity of Moringa oliefera ethanolic extracts (20 to $100 \mu \mathrm{g} / \mathrm{ml})$ compared to standard drug ascorbic acid. Values are expressed as inhibition Vs Concentration 


\section{DISCUSSION}

Indian system of herbal therapy is one of the most common therapies for different types of diseases and disorders. Nowadays the Researchers and Scientist has much more interested in demonstrating and discovering new molecule in plant extract due to plenty of potent antioxidant constituents present in the plant extracts. In the present study selected most common and easily available plant of Moringa oleifera, MTT assay and DPPH assay for antiproliferative and antioxidant activity on HT-29 colon cancer cell line respectively. The Moringa oleifera already has proven an anthelmintic [12], antibacterial [13], antitumor [14], and anticancer [15] pharmacological activity.

MTT assay was most widely used method hence in the present study the extracts were compared with standard drug 5-flurouracil.

In Experiment the test samples mainly ethanolic extract of Moringa oleifera (EEMO) showing growth inhibition of $62.25 \%$ at $100 \mu \mathrm{g} / \mathrm{ml}$ was considered to be active. But an aqueous extract of Moringa oleifera (AEMO) showing \% growth inhibition of 27.86 at $100 \mu \mathrm{g} / \mathrm{ml}$ was considered to be less active when compared with standard 5flurouracil. We concluded that the plant extracts showed in vitro cytotoxicity against HT-29 cancer cell line. The activity might depend upon the morphology of cell lines and mechanism of action of the plant extract and nature of the solvent used for extraction. Many plant extracts kills cancer cell lines through activating apoptosis and effecting growth regulators.

In biochemical systems, superoxide radical can be transformed into hydrogen peroxide by the action of superoxide dismutase and the $\mathrm{H}_{2} \mathrm{O}_{2}$ can subsequently generate particularly reactive hydroxyl radicals in the presence of certain metal ions. Hydroxyl radicals can attack DNA molecules to cause strand cleavage. The DPPH radical is scavenged by antioxidant through the donation of electron forming reduced DPPH. The above explanation is similar effective in ethanolic extract of Moringa oleifera, when compared to standard ascorbic acid in the DPPH assay. The present report depicted in the fig. (2 and 3) and table- 2 were shown that the $\%$ inhibition of aqueous and ethanolic extract were 75.57 and 38.16 at $100 \mu \mathrm{g} / \mathrm{ml}$ respectively. So it was concluded that leaves of plant ethanolic extract Moringa oleifera have antioxidant activity and concentration dependent.

\section{CONCLUSION}

The leaves of Moringa oleifera contain active constituents of saponin, steroids, flavonoids, terpenoids and total phenolics shows an antiproliferative and antioxidant properties. Hence in our study, these active constituents play an important role as an anticancer. Comparing the standard drug 5-FU with ethanolic extract shows the potent effect on HT-29 cell line than aqueous due to the difference in extraction ability of solvents. Finally, the present study was concluded that ethanolic extract of Moringa oleifera has a potent antiproliferative and antioxidant activity.

\section{CONFLICT OF INTERESTS}

Declare none

\section{REFERENCES}

1. Madhuri S, Pandey G. Some anticancer medicinal plants of foreign origin. Curr Sci 2009;96 Suppl 6:779-83.

2. Burali Sanganna, Kulkarni AR. Antioxidant status of fruit peel of Citrus reticulata Essential oil on 1, 2 Dimethylhydrazine induced rat colon carcinogenesis. Res J Pharm Biol Chem Sci 2013;4 Suppl 1:340-9.

3. Alexandra E Tammariello, Milner JA. Mouse models for unraveling the importance of diet in colon cancer prevention. J Nutr Biochem 2010;21 Suppl 2:77-88.

4. Rijin Xiao, Badger TM, Simmen FA. Dietary exposure to soy or whey proteins alters colonic global gene expression profiles during rat colon tumorigenesis. Mol Cancer 2005;4:1.

5. Pamok S, Saenphet S, Vinitketkumnuen U, Saenphet K. Antiproliferative effect of Moringa oleifera Lam. and Pseuderanthemum palatiferum (Nees) Radlk extracts on the colon cancer cells. J Med Plants Res 2012;6 Suppl 1:139-45.

6. Burali Sanganna, Kulkarni AR. Effect of citrus reticulata essential oil on aberrant Crypt foci (acf) development in 1, 2dimetylhydrazine induced colon carcinogenesis rats. Int J Pharm Appl 2013;4 Suppl 1:29-37.

7. Nepolean P, Anitha J, Renitta RE. Isolation, analysis and identification of phytochemicals of antimicrobial activity of Moringa oleifera Lam. Curr Biotica 2009;3 Suppl 1:33-9.

8. Oduro I, Ellis WO, Owusu D. Nutritional potential of two leafy vegetables: Moringa oleifera and Ipomoea batatas leave. Sci Res Essay 2008;3 Suppl 6:57-60.

9. Sreelatha S, Jeyachitra A, Padma PR. Antiproliferation and induction of apoptosis by Moringa oleifera leaf extract on human cancer cells. Food Chem Toxicol 2011;49:1270-5.

10. Sankara Aditya J, Naresh Kumar L, Mokkapati A. In vitro anticancer activities of few plant extracts against MCF-7 and HT-29 cell lines. Int J Pharm Sci 2013;3 Suppl 2:185-8.

11. Burali Sanganna, Kulkarni AR. Antioxidant and anti-colon cancer activity of fruit peel of citrus reticulata essential oil on HT-29 cell line. Res J Pharm Technol 2013;6 Suppl 6:216-9.

12. Rastogi T, Bhutda V, Moon K, Aswar PB, Khadabadi SS. Comparative studies on the anthelmintic activity of Moringa Oleifera and Vitex Negundo. Asian J Res Chem 2009;2 Suppl 2:181-2.

13. Jackson Rafael DP, Silva GC, Costa RA, Lira de Sousa FJ. In vitro antibacterial effect of aqueous and ethanolic Moringa leaf extracts. Asian Pacific J Trop Med 2011;4:201-4.

14. Amelia PG, Vargas C, Sakurai H, Fujiwara Y, Hashimoto K. An antitumor promoter from Moringa oleifera Lam. Mutat Res 1999;440:181-8.

15. Leticia VC, Mahmud TH, Arjumand A, Wilke DV. Studies of the anticancer potential of plants used in Bangladeshi folk medicine. J Ethnopharmacol 2005;99:21-30.

\section{How to cite this article}

- Burli Sanganna, Havagiray R Chitme, Khanvilkar Vrunda, Mohsin J Jamadar. Antiproliferative and antioxidant activity of leaves extracts of Moringa oleifera. Int J Curr Pharm Res 2016;8(4):54-56. 